\title{
KILLSTEALER
}

\section{A shot in the dark.}

BY ALTER S. REISS

"W

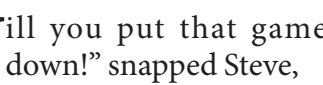
and Brendan turned to his head, looking surprised and hurt.

Steve was immediately sorry. He couldn't yell at what was happening, but snapping at the kid it was happening to wasn't fair. Brendan was just 12 , old enough to understand what was going on, but not old enough to ... not old enough for anything. He looked like he hadn't slept; bruises under his eyes, skin like paper. He looked like he was dying.

"Sorry," said Steve. "Just ... stay with me for a little bit, okay?"

"Okay," said Brendan. "But let me wrap things up. My friends will — " and he looked back at his game and started making excuses into his headset.

Friends, Steve thought. Like the kid had any real friends - just people on the net. I should've pushed harder, with school, with summer camp, things like that. Too late now. He breathed, tried to focus. His job was to be Brendan's father, for however much longer Brendan had.

"There. What is it, Dad? What're you printing?"

There was the click and whirr as the printer finished its job. Best system on the market - laser sintering for four metals, 14 elements total for non-metallic compositions. Should have spent his time with his kid instead of with his toys. "Bots," he said. He took out the capsule it had printed, and passed it over to Brendan. "Here, take this."

Brendan frowned, but took it and swallowed it down with a cup of water. He'd been given a lot of pills to take since they'd found the problem, but he was never a complainer.

By the time Steve had the software set up, the bots were already in Brendan's bloodstream, and the boy was leaning on his shoulder, interested. "Thought it might help to see what's happening," said Steve, which wasn't exactly true. The book he'd been reading recommended showing kids what was going on, and he thought that sounded reasonable.

The screen revealed a confusion of shapes, all moving at different speeds. "That's your blood, you see," he said.

"And those are the cancer cells?"

Steve winced, wishing Brendan hadn't used that word. "No," he said. "The ones outlined in red are the red blood cells. There, that one in yellow is a white blood cell. Some of them are the ... some of them aren't working right."

"Like that one?"

"Yeah," Steve said. "The hairy-looking ones are the bad cells. And check this out." He pressed some buttons, and the bot went forward, into the cell, and it fell apart.

"Cool." Brendan slid in next to him, took over the keyboard.

"If we could do chemo, the bone marrow would stop making - "

"But we can't," said Brendan. "Because of my liver. And we tried other things that didn't work. So I'll pop them."

Steve shook his head, trying not to cry. It had seemed reasonable in the book, but it wasn't going to be easy. "There are too many of them to get. Tens of millions. But you can get a few, give them a fight."

"Thanks, Dad," said Brendan, settling in more comfortably. "Maybe I'll get some of $\rightarrow$ NATURE.COM

Follow Futures: @NatureFutures

f go.nature.com/mtoodm my friends to help are these things networked?"

"I'm not sure," said Steve. He wanted to stay. There wasn't anything he could do, but he wanted to stay. Only, while their insurance was rubbish, if he lost his job, it'd be gone too. "Look, I have to get to work; if you find a better pattern, you can print it out."

"Thanks," said Brendan, but already he wasn't listen-

ing. Trade one game for another, but the book Steve had been reading recommended it as a first step, and it seemed to get Brendan interested.

When Steve got back home, Brendan was still popping cancerous lymphocytes. Maybe it was a mistake, letting him think that he'd be able to beat leukaemia one cell at a time. The idea in the book was that Brendan would get frustrated and stop, and get angry and come back to it, and eventually get used to the idea of how big the problem was.

"How's it going?" Steve asked.

"Oh, that's not me," said Brendan, pulling back, and giving his father a half smile. "Once they started getting bonus points for the spawn sites -"

"The bone marrow?"

"Yeah, the screwed up bone marrow. Even with the cascading bonus for the last few, you can't really get that many points working on me. There're still some guys going for those bonuses, but I'm working on some guy in Fiji who just started printing."

Steve tried to process. "There are tens of millions of cancer cells in your blood," he said.

"Were," said Brendan. "My friends got the interface and the targeting better, and their friends wanted to help too. There's a leaderboard and there are a lot of people playing."

"You're better?" asked Steve, turning Brendan around for a closer look. He still looked like he hadn't slept, but his eyes were clear, and maybe his skin was even a little better.

"Yeah, but this guy ... Dad, you're crushing me. Dad! Oh, man, someone's stealing my kills, Dad!"

Alter S. Reiss is a field archaeologist and scientific editor. His fiction has appeared in Fantasy \& Science Fiction, Strange Horizons, Daily Science Fiction and elsewhere. 